\title{
Copacabana: uma odisséia intraplanetária
}

Reto Melchior Doutor pela Universidade de São Paulo 


\section{Resumo}

Esta "odisséia intra-planetária" expõe uma percepção associativa pessoal do filme brasileiro Copacabana (2001), de Carla Camurati. Comenta o dialogismo explícito com várias obras literárias e cinematográficas, apresenta dois exemplos de intertextualidade visual oculta com pinturas de Mantegna e Picasso e aponta jogos oníricos e técnicas narrativas balizando uma poética do carnaval.

\section{Palavras-chave}

Cinema brasileiro, Carla Camurati, Copacabana, percepção associativa, semiótica visual, dialogismo, intertextualidade, carnavalização

\section{Abstract}

This "intraplanetary odyssey" shows a personal associative perception of the Brazilian film Copacabana (2001), by Carla Camurati. It comments the explicit dialogism with literature and moving pictures, presents two examples of hidden visual intertextuality with paintings by Mantegna and Picasso and designates oneiric and other narrative techniques illustrating a poetic approach to carnival.

\section{Key words}

Brazilian cinema, Carla Camurati, Copacabana, associative perception, visual semiotics, dialogism, intertextuality, carnivalization 
Eu quis um dia, como Schumann, compor

Um carnaval todo subjetivo:

Um carnaval em que o só motivo Fosse o meu próprio ser interior..

Manuel Bandeira

\section{À margem do Danúbio azul}

A

paga-se a luz na sala de cinema e surge, na tela, uma antiga foto azulada, legendada com "Copacabana", mostrando uma mãe com sua filha na calçada da praia; a câmera, lentamente, faz uma panorâmica para a direita; pára; e a foto converte-se numa cena viva, colorida, filmada: um sublime nascer do sol. O grandioso espetáculo é acompanhado por uma trilha sonora que - não nego - emana também uma sensação de grandiosidade: ouvimos, em contraponto às imagens crepusculares do Pão de Açúcar e da reputada praia da ex-capital brasileira, o início do Danúbio azul, valsa símbolo-marca de outro império passado.

Para quem nasceu ao norte dos Alpes, onde as famílias costumavam assistir, no dia do Ano Novo, ao tradicional concerto da Orquestra Filarmônica de Viena, transmitido, desde as beiras do Danúbio, a junção da trilha sonora com a vista de cartão postal sobre a praia carioca é um casamento atrevido - uma mésalliance carnavalesca, na linguagem do crítico russo Mikhail Mikhailovitch Bakhtin (1997: 123). Posso imaginar que essa abertura do filme evoque, na memória de um convicto pé-de-valsa brasileiro, remotas lembranças de um reveillon no Salão Nobre e seus aposentos não menos nobres do hotel Copacabana Palace. Na minha percepção, 
essa combinação de imagem e som na abertura do filme causa certa estranheza - um efeito similar como se Aurora Miranda, ao invés, cantasse Cidade maravilhosa em homenagem à Cidade do Kaiser.

De fato, o mero título do filme de Carla Camurati cria expectativas de assistir a uma obra de enfoque brasileiro, e o espectador aguarda, talvez, que se trate de um remake da comédia musical homônima. ${ }^{1}$ Isso, porém, não é o caso, embora os arranjos musicais em ambas as obras sejam um tutti-frutti de ritmos provenientes de diferentes âmbitos culturais: a Pequena Notável já celebrava os "pampas do Brasil" e Andy Russel homenageava a cidade do samba com "My heart was doing a bolero under the stars in Rio de Janeiro", mesmo ficando com a dúvida referente à autenticidade dos ritmos cariocas: "[...] was it a tango or was it a beguine?".

Para o cinéfilo, a teia referencial do longa-metragem em discussão é outra: a trilha sonora, além de evocar uma festa imperial vienense tipo Sissi, ${ }^{2}$ traz à memória o filme 2001: a Space Odyssey [2001: uma Odisséia no Espaço], que Stanley Kubrick realizou um ano antes da primeira alunagem. A fantástica viagem pelo universo, pré-datada para o ano 2001 - que, dentro do quadro referencial da fita, corresponde a quatro milhões de anos depois da descoberta de um monólito enigmático pelos macacos antecessores da humanidade - efetua-se com o mesmo fundo musical que a obra da cineasta carioca. Copacabana, lançado em 2001, alude ao principal clássico da ficção-científica de 1968 que, aliás, também exibe um sublime levantar do sol.

1. Comédia musical de Alfred E. Green, realizada em 1947, com Carmen Miranda E Groucho Marx nos papeis principais, que se passa no mundo do show business norte-americano: o agente Lionel Q. Devereaux (Groucho Marx), para superar suas dificuldades financeiras, trata de conseguir um contrato para Carmen Navarro, uma cantora latino-americana (Carmen Miranda), no famoso clube Copacabana de Manhattam . Suas negociações malandras levam à situação que sua namorada - e única esperança - precisa aceitar dois engajamentos ao mesmo tempo: um como Carmen Navarro, cantora brasileira, e outro como Mademoiselle Fifi, uma loira franco-marroquina, apresentando-se em público só com o tradicional véu sobre o rosto.

2. Filme austriaco, realizado em 1955 por Ernst Marischka, com Romy Schneider no papel da imperatriz. 
O mero fato de citar autoridades - falsas ou corretas - no início de um enunciado enquadra a obra numa contextura cultural determinadora, que envolve o espectador num clima de expectativa alusiva, dando-lhe a licença explícita de explorar os esconderijos de recônditas significações. "Nous n'avons qu'une voie possible : regarder le discours poétique comme l'établissement d'une équivalence entre un mot et un texte, ou entre un texte et un autre texte", concluiria o autor de L'illusion référentielle, Michael Riffaterre (in: Barthes et alii, 1982: 99).

A suposta citação daliniana, que responsabiliza o autor francês dos romances De la Terre à la Lune [Da Terra à Lua] e Autour de la Lune [À Roda da Lua] pela ansiada morte-viagem do ser humano, afere-se com a evocação de uma obra de ficção científica no prólogo do texto filmico, embora a "viagem interplanetária" aludida não seja da autoria de Jules Verne, senãe de Stanley Kubrick.

No seguinte trecho da fita, a câmera enquadra lentamente o interior do apartamento luxuoso, que oferece a seus moradores uma vista panorâmica privilegiadíssima sobre a praia de Copacabana. ${ }^{4}$ Dentro, reina um ambiente de day after de uma festa exuberante: bexigas, copos, presentes, até uma boneca inflável embrulhada em papel celofane; e vislumbram-se as silhuetas dos convidados adormecidos nas poltronas ou nos sofás.

Atílio (Luís de Lima), um dos convidados que acaba de assistir, no terraço do apartamento, ao espetáculo matinal do levantar do sol, interrompe o silêncio dentro da sala convertida num dormitório improvisado, para acordar os tresnoitados adormecidos: "Gente, o sol já está nascendo. Vamos lá, vamos! A que horas é o enterro?"

Veja também o artigo "O tempo mnésico da enunciação e o tempo crônico do enunciado em Carlota Joaquina", de Geral do Carlos do Nascimento (2001: 4563).

4. Esse interior elegante, com sua vista de cartão postal, evoca em mim o cenário principal de Mujeres a borde de un ataque de nervios, que Pedro Almodóvar realizou em 1987. Pepa (Carmen Maura), mal casada com um militar de carreira, reina nesse ambiente inexistente em Madri: a vista sobre a estátua do Anjo Alado, a Gran Vía madrilena e sobre o prédio da Telefônica dispensa o filme de sua veracidade, deslocando-o num molde da ficção, da comédia. 
Carla Camurati, da parte dela, prepara o espectador aos poucos para uma odisséia cinematográfica através de outro espaço desconhecido, no decorrer da qual será descoberto - em vez dos segredos do planeta Júpiter - o "planet Copacabana", cantado por Bia PONTES num rap que, abruptamente, substituirá a valsa vienense inicial.

O levantar do sol sobre a praia carioca remete, dentro desse jogo alusivo, às seqüências iniciais da primeira parte da obra-mestra de Kubrick, intitulada "The Dawn of Man" ["A Aurora do Homem"]. Mas o cenário panorâmico de Copacabana fecha-se lentamente e, num plano-seqüência que passa do exterior para um interior, termina enfocando - em vez de uma família de macacos - uma turma bastante heterogênea, alegremente vestida, dormindo nas poltronas e nos sofás de um luxuoso apartamento da avenida Atlântica. Uma voz, proveniente de um espaço em off, comenta:

\section{É... Salvador Dali tinha razão: cada vez que alguém morre na terra, o culpado é Júlio Verne. Foi ele que inventou o desejo por viagens interplanetárias. Talvez todas estas pesquisas biológicas façam que o homem não morra. Porém, enquanto isso...}

Sobressai, nessa fala, a insistência em citações para legitimar a veracidade da colocação do Narrador invisivel, embora fique minha dúvida de que a frase seja realmente da autoria do pintor catalão, que - seja lembrado à parte - foi citado também no prólogo do primeiro longa-metragem de Carla Camurati, Carlota Joaquina, princesa do Brazil (1994). ${ }^{3}$

3. O jogo referencial é o seguinte: um jovem escocês procura, à beira do mar, uma menina de dez anos: Yolanda está zangada com seu tio porque ele riu dela quando dançavam. Para fazer as pazes, o jovem parente oferece-lhe seu exemplar de Robert Burns, mas ela não aceita. Ao ver então uma garrafa no mar, o tio vai pescá-la, se por acaso ela conter um mapa para eles acharem um tesouro e ficarem ricos. A garrafa contém uma página de livro sobre Salvador Dali, que alude à existência de borboletas gigantes no Brasil que sugam o cérebro das pessoas. O jovem, brincando com a menina, insiste afirmando que, de todos os problemas brasileiros, o das borboletas gigantes é o pior. E como sabe muitas histórias maravilhosas, convém em contar, para a sobrinha, a vida da princesa Carlota Joaquina, princesa do Brazil. 
E enquanto a câmera enfoca um caixão na sala vizinha, continuam girando, na trilha sonora, os compassos alegres da valsa.

A confusão é tal que o espectador mal consegue entender o que acontece. Por um lado, estamos acareados a uma conjuntura clássica de tragédia: numa situação limiar, à beira de um caixão ainda aberto, ${ }^{5}$ e por outro lado, o ambiente - metonimicamente representado por gestos teatrais, roupas extravagantes, uma maquilagem exagerada e umas perucas mal ajeitadas - evoca o mundo da comédia ou da farsa.

Segue-se o fechamento do ataúde, ao passo que Rogéria (a própria), uma cinqüentona vestida de crepe pink, serve café aos assistentes. Salete (Walderez de Barros), uma velhinha lamenta: " $A$, Alberto, por que você me deixou?" E replica-lhe Salma (Laura Cardoso), outra igual: "Salete, como ele pode ter te deixado se ele nunca foi teu?"' Enrico (Pietro Mário) segura a tampa do caixão e,

5. Walter Salles, nas pesquisas sobre a estrutura da tragédia grega a respeito da filmagem do livro Abril despedaçado, do autor albanês Ismail Kadaré, chega à definição de que "a fossa do morto e o espaço que a cerca sảo ao mesmo tempo a matéria-prima e a primeira cena do teatro trágico. O personagem principal, o morto, está entre dois reinos rivais - a vida e a morte. Como não é mais capaz de falar de si, outros o farão por ele. Essa incumbência caberá às primeiras atrizes profissionais que, segundo Kadaré, são as rezadeiras. Os seus lamentos codificados pertencem ao território da realidade interpretada, como o coro antigo o faria mais tarde no teatro grego. Ainda em grego, a palavra ator se traduz por hypokritês. É uma definição que cabe como luva às profissionais que choram um morto que năo thes pertence" (Butcher, 2002: 81).

6. Em 1997, Carla Camurati participou do projeto do "primeiro filme de ópera brasileiro" com uma versão cinematográfica de La serva padrona (1733), de Gianbatista Pergolesi, e em agosto de 2002, ela assumiu a direção cênica de Madama Butterfly (1904), de Giacomo Puccini, no Theatro Municipal de São Paulo. Já que a ópera italiana pertence ao molde cultural da artista, è bern possivel que os traços constituintes do sintagma ecoem o início da opera buffa italiana Gianni Schicchi (1918), de Puccini: em volta do leito mortuário de Buoso Donati, choram os parentes, ávidos de herdar os bens do defunto, enquanto Gherardino, um menino de sete anos, está tranqüilamente brincando com bolinhas de gude. As lamentaçōes em ambas as obras soam pouco convincentes, e, embora na metábole filmica ninguém almeje uma herança futura, como no paradigma do libreto, é minima a diferença entre o "Ai, Alberto, por que você me deixou?" e o "Povero Buoso! Povero cugino! Povero zio! Oh! Buoso! Buoso! O cognato! O cogna...". 
entre gritos e choros de carpideiras, tenta fechar o féretro, sem consegui-lo direito, porque Celima (Myrian Pires) tinha colocado uma estátua de Nossa Senhora de Copacabana ao lado do defunto Alberto (Marco Nanini), seu irmão adotivo; e a santa impede o fechamento. Com câmera subjetiva em contre-plongée, na posição do corpo morto, assistimos à reabertura do caixão. Um dos enlutados opina que nunca se viu enterrar alguém com uma santa junto, enquanto várias cabeças femininas despenteadas se inclinam para despedir-se mais uma vez do falecido. Uma lágrima molha a lente, ou seja, o olho do morto, cuja voz comenta em tom calmo e objetivo:

Eu não me incomodo que penteiem meus cabelos nem que me sufoquem com flores. Mas precisa tanta lágrima?

A câmera subjetiva faz com que o espectador assista à narrativa por um "olho morto" dentro do caixão. Esse deslocamento virtual aproxima as posições do enunciador e do enunciatário, por colocar ambos num espaço em off. Quem assiste ao filme, é posto no lugar que a condução expressiva do relato lhe confere: na posição do defunto. Mas o Narrador, pelo fato de comentar seu próprio velório, deixa de ser o personagem da ficção: quem segue falando não pode ser o defunto, senão o ator Marco Nanini, o 'gpokrith, j [hypokritês], segundo a definição de Ismail Kadaré.

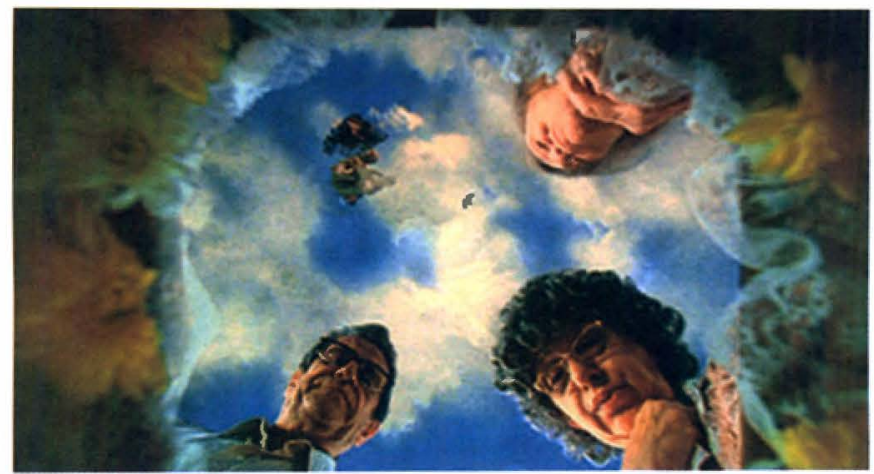


A imagem que o olho enfoca desde dentro do caixão remete, na minha opinião, a uma obra que o pintor italiano Andrea Mantegna (1431-1506) realizou no Castello San Giorgio, em Mántova (Itália). ${ }^{7}$ Uma clarabóia pintada no teto da chamada Camera degli Sposi [Quarto dos Noivos] abre a visão a um céu ligeiramente anuviado. Detêm-se, na borda da abertura, entre uma laranjeira de um lado e um pavão do outro, uma dezena de anjinhos e cinco mulheres; três delas olham para baixo, como querendo saber o que acontece nos aposentos do duque. Há, além disso, escondido na maior nuvem, um auto-retrato do pintor que, com essa presença discreta, dá a entender que está a par dos segredos da corte dos Gonzaga. O "óculo" pintado no teto, além de designar uma abertura arquitetônica, torna-se o "olho" da indiscrição. Carla Camurati, na tomada em contre-plongée dos velhinhos que se assomam sobre o caixão, abre o jogo alusivo com a obra finória de Mantegna, opondo assim à temática do voyeurismo, no próprio sentido da palavra, um voyeurismo cinematográfico in extremis. Inclino-me a definir o modo de enfocar a cena pelo olho da câmera como "assinatura íntima"s que a cineasta carioca outorga ao filme - comparável ao concetto mantegnesco, que marca, (in)discretamente, a presença do autor no retrato metamorfoseado numa nuvem.

7. Veja a descrição da pintura no palácio mantovano no capítulo "The Camera degli Sposi" em Nike Bätzner, 1998: 50-73.

8. Uso a definição de Daniel Arasse, em Le détail (1992: 222): “Les trois signatures (publique, privée, intime) qu'il appose, entre 1465 et 1474, dans la Chambre des Époux du palais ducal de Mantou montrent aussi comment l'investissement personnel de ce thème se manifeste à travers une mise en œuvre du détail qui confine, cette fois, à l'invisibilité". 


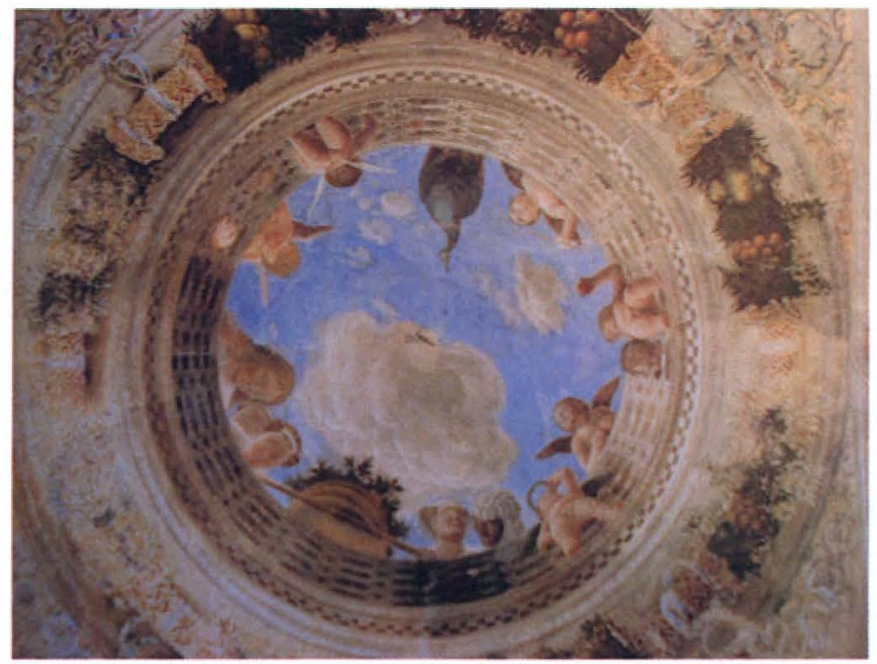

Surpreende, além disso, a voz do defunto que comenta a cena da própria morte e se dispõe a contar sua vida. Copacabana começa pelo final dos acontecimentos, e a narrativa do filme tramarse-á na retrospectiva, igual ao romance machadiano, Memórias póstumas de Brás Cubas (1880/81), que também começa a história pelo final:

Algum tempo hesitei se devia abrir estas memórias pelo principio ou pelo fim, isto é, se poria em primeiro lugar o meu nascimento ou a minha morte (Assis, 1988: 25).

Notamos os paralelos com Brás Cubas, já que o espaço em off, de onde surge a voz do Narrador, parece ser, em ambas as obras, um além. Mantém-se, no percurso do filme, essa voz machadiana que comenta o conjunto das cenas da vida de Alberto desde o momento em que o recém-nascido foi abandonado à porta da igreja de Nossa Senhora de Copacabana até o dia de seu nonagésimo aniversário.

Dois anos antes de Copacabana, no êxito mundial e ganhador de cinco Oscars, American Beauty [Beleza americana], o cineasta Sam Mendes usou um enfoque narrativo comparável: o personagem 
principal, Lester Burnham (Kevin Spacey), dirige-se ao espectador para apresentar-lhe o bairro onde mora com sua família e anuncia que o filme exibirá a história do último ano de sua vida:

My name is Lester Burnham. This is my neighborhood. This is my street. This is my life. I'm 42 years old. In less than a year, I'll be dead. Of course, I don't know that yet. And in a way, I'm dead already.

Nas últimas cenas, que mostram o assassinato de Lester, a câmera adota também a visão do protagonista morto, que continua reflexionando sobre o sentido da vida. Em Copacabana, o enfoque narrativo é comparável e Alberto faz o mesmo tipo de considerações que Lester, ao refletir sobre os momentos fúteis de seu passado:

Quando a tampa fecha, fecha-se o ciclo da vida. Duas datas: a do nosso nascimento e a da nossa morte. E no meio uma infinidade de acontecimentos: amores, dores, almas que se esgarçam. E por fim: a tampa.

$\mathrm{O}$ fato de que um defunto apresente sua própria vida, afasta o sentimento macabro que, normalmente, fica pego a uma cena de vigília mortuária, e a trilha sonora festiva sustenta a mudança da situação trágica em uma tragicomédia. Alberto, ao dirigir-se ao espectador do filme para contar-lhe seu próprio nascimento, na hora de sua morte, torna-se um Narrador onisciente e vivo fora da teia da ficção:

E antes que algum dos meus amigos suspire e exclame: "Coitado! Até que enfim descansou!", vamos ao começo de tudo.

Um dia, nem belo, nem feio, um dia como tantos outros, eu nasci. Fui abandonado à porta da antiga igrejinha de Copacabana, bairro onde acabei por viver toda minha vida. Era noite alta, e eu devo ter chorado muito, até que, lá em cima, alguém ouviu minhas precoces preces. 
E assistimos, na sala de cinema, ao choro da criança que comove a própria Virgem de Copacabana (Mabel BIANCO); ela, por viver longe de sua casa, sente-se sozinha também. Acudindo, a Santa toma o enjeitado nos braços e, para acalmá-lo, conta-lhe, em espanhol, a história de sua origem: vem de um povo que adorava o Sol e era o ídolo que tomava conta do lago Titicaca, num santuário chamado Kopakawana; transformou-se numa Santa católica, quando os espanhóis, comandados por Pizarro, invadiram o Peru, cuja destruição foi total, e nada restou do império; os invasores trouxeram também uma nova religião. Anos depois, descansando no lago, ela ouviu a voz de um índio: Tito Yupanqui, descendente do último Imperador inca; e foi esse índio que esculpiu sua primeira imagem: uma Virgem vestida de sol, com a lua sob seus pés e, na cabeça, uma coroa com doze estrelas. A imagem tinha feições indígenas e, por isso, ninguém a aceitava, até que ela começou a fazer milagres e sua fama se espalhou por todos os lados. Como era a rainha das águas, saía em todas as embarcações; uma deixou-a perto de uma bela praia chamada Sacopenapã e, em poucos anos, ela já tinha aquela igrejinha, naquele lugar que em sua homenagem passou a se chamar Copacabana. $^{9}$

O relato, acompanhado de música incaica e elucidado com imagens animadas, baseia-se nas lendas populares da Virgem patroa. No fio narrativo da fita, a Protetora, ao depositar a criança no altar da igreja, intervém pela voz e pela projeção de uma sombra viva.

9. Veja a importância que Mikhail Bakhtin (2000: 274) atribui à introdução de elementos folclóricosna Estética da criação verbal, cujas conclusões mantêm a mesma validade na análise de um texto fílmico: "A canção popular, o conto, a lenda heróica e histórica e a saga eram um meio novo e eficaz de conseguir uma humanização e uma condensação do espaço que a pátria representa. [...] O folclore, de uma maneira geral, está saturado de temporalidade; todas as suas imagens são profundamente cronotópicas. O tempo no folclore - a plenitude temporal, o futuro, as medidas do tempo do homem - colocam importantes problemas que nada têm de inatual. [...] Aqui nos interessa mais diretamente outro aspecto da questão: o uso do folclore local (particularmente da lenda e da saga heróica que visam a intensificação da percepção da terra natal) tal como ele aparece no processo que culmina no romance histórico. $O$ folclore local pensa e informa o espaço, satura-o de tempo e incorpora-lhe a história". 
O milagre provoca o assombro dos padres que acham o menino no santuário fechado. Acabam batizando-o com o nome de Alberto. "E foi assim que fui encontrado misteriosamente no altar", conta o nonagenário defunto ao espectador, enquanto a Virgem-ex-ídolo-inca-mãe-adotiva do rejeitado exclama:

$Y$ después de tantas aventuras, aqui estamos, niño: ¡Copacabana!

$$
* * *
$$

\section{Bia PONTES - Planet Copacabana}

Aqui nesse planeta, bem pertinho do mar,

Nasci e me criei e aprendi a me virar.

Logo cedo percebi que não dava pra aturar:

Mãe viúva, cinco irmãos e um padrasto a me secar. $E$ de repente, olhando de relance para a rua, não me pareceu

Que a noite fosse tão escura e, pensando bem,

Melhor seguir outro caminho.

Se eu ficar, o bicho come no meu próprio ninho.

Eu sou do planet Copacabana! E a princesinha do mar tá fazendo a maior grana À beira da praia, bem junto ao céu. Só falta descolar outro cliente e um papel.

Eu sou do planet Copacabana!

E pra você, eu estou fazendo a oitenta essa semana. Dezesseis aninhos de puro prazer! Eu faço de um tudo; que é que vai querer? Copacabana! Aqui no planet, no planet Copacabana! Copacabana! Aqui no planet, no planet Copacabana! Aqui nesse planeta, bem pertinho do mar, Ainda sobra muito tempo pra gente sonhar.

Qualquer dia, num programa, ainda vou encontrar Um gringo cheio do "dim-dim", que vai por mim se apaixonar, Me levar pro seu país e comigo se casar. 
Vou ter um filho de olho azul E muito money pra gastar,

Ou então, fazendo a vida, vou juntar meu pé de meia Pra poder me aposentar quando estiver mais velha e feia.

Eu sou do planet Copacabana! E a princesinha do mar tá fazendo a maior grana A beira da praia, bem junto ao céu. Só falta descolar outro cliente e um papel. Eu sou do planet Copacabana!

E pra você eu estou fazendo a cinqüenta essa semana.

Vinte e dois aninhos de puro prazer! Eu faço de um tudo pra poder viver. Copacabana! Aqui no planet, no planet Copacabana! Copacabana! Aqui no planet, no planet Copacabana! Mas aqui, nesse planeta, bem pertinho do mar, A maré não tá pra peixe, já não dá pra faturar.

Estou com vinte e oito, e já estou meio caida, E o dinheiro não tá dando pra pagar a cocaina.

Moro numa vaga já há doze anos. Mas viciada não consigo juntar nada do que eu ganho. Carro já não pára. Tem em cada esquina Uma garota de quatorze que é a nova princesinha De Copacabana, aqui do planet, do planet Copacabana. De Copacabana, aqui do planet, do planet Copacabana.

Eu sou do planet Copacabana! E a princesinha do mar tá fazendo a maior grana À beira da praia, bem junto ao céu. Só falta descolar outro cliente e um papel. Eu sou do planet Copacabana!

E pra você, eu estou fazendo a vinte e cinco essa semana. Já não digo a minha idade, já não dou tanto prazer. Mas eu faço de um tudo pra sobreviver. Copacabana! Aqui no planet, no planet Copacabana! Copacabana! Aqui no planet, no planet Copacabana! Copacabana! Aqui no planet, no planet Copacabana! 
Copacabana! Planet Copacabana! Copacabana! E a princesinha quer mais...

\section{«Aqui nesse planeta, bem pertinho do mar... »}

Ressoa ainda, nos ouvidos do espectador, o choro da criança no altar da igreja e a exclamação de Nossa Senhora quando se entoa, em plena oposição à valsa inicial, o Planet Copacabana. Enquanto isso, passa a sombra do nonagenário sobre o mosaico inconfundível da calçada carioca e se projetam os créditos do filme.

Essa seqüência contrasta com a cena inicial do velório tanto pela trilha sonora, como pelo realismo documentário com que se mostra Copacabana: o espetáculo habitual de banhistas, turistas, prostitutas, travestis, vendedores ambulantes, mães com crianças, um bloco com sua porta-bandeira, sambistas, um grupo de jovens fantasiadas, uma capoeirista; e também uma série de pessoas idosas, que não só constituem parte considerável dos moradores do bairro, mas também dos protagonistas do filme. E, discretamente, intercalamse, nesse registro ambiental, os atores principais: Fanny (Ida Gomes) e Isaac (Felipe Wagner), discutindo no meio da rua; Celima (Myrian Pires), comprando um frango assado; Alberto, uma vez jogando baralho com três amigos e depois falando com um vendedor de cachorrinhos, a insaciável Jacira (Ilka Soares), tomando banho ao compasso da trilha sonora, no momento em que Bia Pontes canta "princesinha do mar". Acabam-se os créditos, e a câmera enquadra o interior do apartamento que já conhecemos.

Alberto está frente a sua estátua da Virgem de Copacabana, tocando-a carinhosamente, e olhando para seu animal de estimação: uma tartaruga ${ }^{10}$ que - entre um ídolo representando a deusa pré-

10. No Making of do filme, há uma discussão entre Carla Camurati e Marco Nanini com respeito ao animal doméstico de Alberto, e a cineasta insiste, sem outras explicaçōes, em que seja uma tartaruga. Vemos, na escolha do animal, uma imagem do próprio protagonista, já que, em sentido figurativo, usa-se o termo para designar "uma pessoa velha e feia" (cf. Aurélio, 1986: 1652). Além disso, o animal é proverbial pela sua longevidade, citada, por exemplo, por Eurico Santos, em sua Historia, lendas e folclore de nossos bichos: "Havia, há 
incaica do lago Titicaca e os pés da Rainha das águas, adereçada como santa católica - come, tranqüilamente, uma folha de alface, enquanto ouvimos: "Copacabana! E a princesinha quer mais...".

A cena seguinte mostra a turma de amigos de Alberto na praia. Os velhinhos comentam a ausência de Alberto, por não vir mais à praia faz dois dias; tocam o assunto da festa de aniversário, querendo que ela seja bem alegre, e falam da sorte de chegar aos noventa anos. A câmera, então, enfoca a praia desde o apartamento do aniversariante, cuja voz acrescenta:

Sorte? É, talvez seja uma sorte chegar aos noventa. Era disso que eu me tentava convencer, trancado em casa, naqueles dias que antecederam meu aniversário. Mas estava dificil. Sabe qual é o problema? Noventa anos é uma idade impossivel de se pensar num futuro alegre. Por isso, talvez, a cada lugar que olhava, uma memória longinqua me surpreendia.

Alberto, deixando de lado café e jornal, levanta-se e vai à janela, para olhar a praia com um binóculo. A cena surpreende o espectador pela incoerência temporal: anoitece de repente. A câmera subjetiva imita o olhar do curioso, e a imagem colorida torna-se monocromática, trazendo à tela uma cena da infância do protagonista, quando assistia, com Celima, à histórica Revolta do Forte de Copacabana de 1922, que, segundo os historiadores, assinalava "o inicio da ação tenentista e sua ampla repercussão na sociedade", e cujos "revoltosos foram considerados heróis pela coragem mostrada no enfrentamento das tropas governistas, que a alguns deles valeu a morte" (Rezende, 1991: 19). "Mas foi ali a primeira vez que eu vi um homem morrer", comenta Alberto. Acaba-se o flash-back e o filme retoma a iluminação diurna e a colorização normal.

poucos anos, e talvez ainda lá esteja hoje, na ilha de Santa Helena, a tartaruga que foi vista pelos olhos de Napoleão" (apud Aurélio, 1986: 1047).

Numa gregueria de Ramón Gómez De La Serna (1955: 1316) lemos: "La tortuga no tiene prisa porque está caminando de un siglo a otro". 
Na manhã seguinte, Alberto corre à igreja, para "trocar uma palavrinha" com sua Santa, e ela anima-o - em espanhol, como sempre - para deixar de lado saudade e tristeza:

¡Cuántas lemurias, Alberto! ;Va, anda, conmemora la vida!

Ao sair, a caminho da padaria, para o café matinal, a presença imagética de Alberto duplica-se e o filme muda de cor, substituindo o presente por uma série de documentários: banhistas, uma mãe que leva uma criança a um passeio (a mesma tomada já saiu na abertura do filme), um fotógrafo na praia; segue uma montagem que mostra $o$ protagonista na calçada - como se ele já tivesse noventa anos, na década de vinte - e voltam as filmagens históricas originais: uma multidão, nas sacadas das casas, observando os acontecimentos na rua, um grupo de mulheres com chapéu e sombrinha, e, de novo, uma imagem - mas agora envelhecida - do passeio de Alberto; assistimos a uma gincana, ao movimento frente ao Copacabana Palace, a uma corrida de cavalos, vemos uma criança de bicicleta na rua, uma panorâmica do prestigioso Palace inaugurado em 1923. E escutamos a voz de Alberto que, desde o espaço em off, procura uma explicação do que está acontecendo:

$E$ de novo aquela sensação estranha: era como se Copacabana fosse feita de uma matéria elástica. Ia e vinha compondo fotografias que eu nunca tirei. E eu era - um viajante no passado, um espectador de imagens gravadas há muitos anos na retina, há muitos anos... Imagens que eu nem sabia que existiam dentro de mim. E eu era tudo: era eu criança e velho ao mesmo tempo, tempo, tempo, tempo, tempo, tempo, tempo...

Corte. $\mathrm{O}$ filme volta à seqüência anterior, com o protagonista em casa, sentado à mesa e folheando um álbum de fotos. Seus pensamentos estão virados para seu próprio passado, e os meandros narrativos acompanham o protagonista em suas lembranças: ele, na praia com sua irmã; ele, num campanário enquanto os responsáveis 
abaixo gritam insistindo que desça para não cair; e ele - em rigor: a câmera subjetiva - caindo da torre da igreja. Mais um corte. Alberto acorda assustado.

O espectador, a essa altura do filme, pergunta-se, com razão, quantas das cenas assistidas eram sonhadas, e quem as sonhou. A técnica remete, dentro do mundo da sétima arte, aos jogos oníricos de Luis Buñuel, cuja importância salienta Charles Tesson (1995: 63), em seu livro sobre o cineasta, citando a seguinte colocação de Friedrich Nietzsche:

Vous voulez être responsable de tout! Sauf de vos rêves! Quelle lamentable faiblesse, quelle absence de courage logique! Rien n'est davantage votre auvre!

Vista a importância atribuída ao sonho em geral - e no cinema em particular -, deixarei a interpretação do pesadelo da queda da torre da igreja, que assusta Alberto ainda na velhice, para quem entenda de psicanálise, já que Sigmund Freud não se atreve a formular uma conclusão inequívoca, remetendo para uma análise individual de cada caso:

Zur zweiten Gruppe von typischen Träumen gehören die, in denen man fliegt oder schwebt, fällt, schwimmt $u$. dgl. Was bedeuten diese Träume? Das ist allgemein nicht zu sagen. Sie bedeuten, wie wir hören werden, in jedem Falle etwas anderes, nur das Material an Sensationen, das sie enthalten, stammt allemal aus derselben Quelle (Freud, 1989, II: 384). ${ }^{11}$

Eduardo Peñuela Cañizal (1993: 19), adentrando-se no Obscuro objeto da ambigüidade, escreve com respeito à representação de referentes oníricos na obra do cineasta aragonês:

11. ["O segundo grupo de sonhos tipicos consta daqueles em que se está voando, pairando, caindo, flutuando, etc. Que significam esses sonhos? Isso não pode ser dito em geral. Significam, como vamos ouvir, outra coisa em cada caso; só o material de sensaçōes que contêm sempre provém da mesma fonte"]. 
Talvez não tenha sido ainda bem analisada a importância que têm as ambigüidades construidas por Luis Buñuel para delimitar um instigante espaço expressivo. Refirome especificamente a esse espaço do significante cinematográfico em que as fronteiras entre a exterioridade e a interioridade do mundo representado se confundem e, com isso, o espectador se transforma, metaforicamente falando, num espelho onde as imagens refletidas não encontram uma clara resolução. Do porto de vista estilístico, esse traço afigura-se como uma das características expressivas mais típicas dos filmes do cineasta espanhol.

Cai em suspeita que assistimos a um sonho de Alberto desde a cena fúnebre do início do filme, já que o luto dos amigos, em estilo de comédia pura, opõe-se radicalmente às imagens lembradas, que correspondem a trechos de filmes documentários. Buñuel, em Le charme discret de la bourgeoisie [O Discreto Charme da Burguesia], de 1972, também encaixa um sonho dentro do outro, seguindo o modelo dos bonecos russos que, ao abrir uma iàòd, øêa ["matrioshka"], tem ainda outra menor dentro. No âmbito da literatura, cabe citar Jorge Luis Borges e seus contos de sonhos emaranhados. ${ }^{12}$

Alberto, ao despertar, tenta lembrar-se do o que aconteceu. Sabendo que perdeu a hora, veste-se e sai para a rua, enquanto dois funcionários do prédio renovam suas apostas, torcendo para que o inquilino mais velho chegue - ou não - aos noventa anos. Alberto

12. Em Borges, porém, o jogo da vida sonhada evoca um sentimento de pesadelo, às vezes, já formulado no título - veja La pesadilla, do livro La moneda de hierro (1976), que termina pela frase: "En aquel preciso momento senti el inconfundible sabor de la pesadilla y me desperté" (BORGES, 1989, III: 428). Borges - seguindo o modelo de Pedro Calderón De La Barca - retoma uma técnica barroca, elaborada, por exemplo, em La vida es sueño.

Compare-se também como se encaixam diferentes pesadelos no conto Las hojas del ciprés, publicado em Los conjurados (1985), com o efeito de nunca saber qual é o grau zero da narração. Tempo e Espaço, quando perdem sua ancoragem cronotópica, anulam-se e passam a um eixo determinado por um Não-Tempo e um Não-Espaço. 
passa na cervejaria, onde três amigos já estão jogando uma partida de baralho sem ele, pede desculpas pelo atraso e alega que tem um compromisso no Palace. Passa apressado pela multidão, que povoa, no começo da noite, a avenida Atlântica, enquanto volta, na trilha sonora, Planet Copacabana.

A voz do Narrador confessa que seu maior vício sempre foi o jogo, que apostou em roletas, cavalos, cartas, mulheres, que apostou muito na própria pessoa, algumas vezes na vida, sempre na noite, e nunca na morte. Alberto chega ao terraço do hotel, onde Celima o está esperando. Esta constata que seu irmão adotivo tem um comportamento estranho, e Alberto confessa-lhe que tem medo de morrer. Animam-se ambos, enfim, para beber uma taça de champanhe.

Ao brindar, surgem, diante dos olhos de Alberto e do espectador, novas lembranças de sua longa vida, que levam a um baile de Rádio Nacional no próprio hotel: Alberto, dançando com o grande amor de sua vida, Miloca. Celima estimula as lembranças comuns, e a voz de Alberto-Narrador explica que ele foi adotado pela família dela quando tinha nove anos. Elogia Celima como sua melhor amiga e manifesta também seu carinho incondicional que tem com todos seus amigos, chamando-os de "bando de velhos simpáticos e loucos".

Enquanto isso, os amigos preparam a festa contra a manifesta vontade do aniversariante. $O$ filme passa a mostrar uma reunião do comitê organizador, em que se misturam os preparativos do evento e as conversas fofoqueiras ao baralho, filmado num plano-seqüência de quatro minutos: a câmera borboleteia em torno da mesa dos jogadores, elucidando a eterna roda do jogo e o repetitivo assunto da conversa.

Alberto, na volta para casa, pára no terraço de um restaurante para beber uma margarita - em honra, talvez, de Miloca, que vendia margaridas na praia, quando chegou a conhecê-la. Edinho, um menino de rua, engraxa-lhe as sandálias.

Passa Rogéria, com um vestido azul-Yemanjá e um chapéu montado e em nada inferior a qualquer turbante tutti-frutti de Carmen Miranda do Copacabana de 1947: seu resguardo da cabeça - um 
verdadeiro carro alegórico em miniatura - representa a praia com guarda-sóis de enfeite para sorvetes, transvertendo essa princesa da calçada numa sobremesa. A autêntica personagem carioca entra em cena como viva alegoria humana de Copacabana e convida Alberto para assistir a seu show, que começa dentro de meia hora.

Passa uma garota que suscita nele a remota lembrança de Madame Cosette, "francesa de araque" que, na sua juventude, fazialhe, "literalmente, explodir de desejo". Alberto segue a desconhecida e, confundindo o presente com o passado, imagina que entra no estabelecimento da Mère Louise, "casa mais suspeita da infância de Copacabana". Volta a si e reconhece o engano: o nonagésimo importunou "a nova" da boate, em cima de uma mesa do bar.

Sozinho, na calçada, Alberto reflete sobre a confusão que armou; afirma, porém, que o desejo não morre, nem com a idade, e cita o comportamento de sua amiga Jacira, de setenta e oito anos, que, assistindo a um show na TV, é surpreendida, pela própria filha, em circunstâncias delicadas: e nem os trabalhos macumbeiros - uma calcinha com espadas de Ogum - apagam, na velha dama, o incessante fogo do desejo.

Ao chegar em casa, Alberto leva o susto da surpresa: sua turma de terceira idade e o "planet Copacabana" inteiro recebemno, no apartamento enfeitado, com aplausos, a festejar. Prepararam um bolo enorme, representando a igreja onde ele foi encontrado com o fotógrafo Alberto na frente, e há uma infinidade de presentes. Rogéria, que assistia à confusão na boate, entrega ao aniversariante uma boneca inflável; todos contam piadas e improvisam apresentações musicais, começando por La petite Tonkinoise e Hava nagila; canta então Jacira, com um chuchu na mão, O teu cabelo não nega; Salete e Salma evocam os tempos passados com Abre alas, de Chiquinha Gonzaga, e Rogéria interpreta Rosa, de Pixinguinha. Alberto confessa que está adorando a festa e conclui que, assim, ele "faria noventa anos durante todos os noventa anos" de sua vida. Todos começam a dançar e, entre ritmos brasileiros e internacionais, entoase de novo a valsa vienense $O$ Danúbio azul.

Quando cantam os parabéns para o festejado, visivelmente emocionado, a voz emocionada do Narrador, desde seu espaço em 
off, recita os primeiros versos de Belo belo, poema do livro Lira dos cinqüent'anos, de Manuel Bandeira (1990: 260):

Belo belo belo,

Tenho tudo quanto quero.

Tenho o fogo de constelações extintas há milênios.

$\mathrm{O}$ aniversariante apaga as velas e extinguem-se, inesperadamente, as imagens da festa, como se a filmagem substituísse o quarto verso do poema:

E o risco brevíssimo - que foi? passou - de tantas estrelas cadentes.

É de manhã. Alberto está deitado à beira do mar, com os olhos fechados e os óculos jogados na areia. Passa em procissão, com música andina, a Virgem de Copacabana, levada a ombros sobre um andor em forma de bolo de aniversário. Aproximam-se dois pescadores que reconhecem Alberto. Procuram ajuda por não saber, se ele está bêbedo ou morto. Corte.

Os dois empregados do condomínio - o vencedor e o vencido na aposta referente à morte de Alberto - levam um caixão para dentro do prédio.

No apartamento, começa o velório com um choro feminino. A câmera subjetiva reitera o enquadramento conhecido, em contreplongée, na posição do morto no féretro, e o quadro mantegnesco acresce, às cabeças inclinadas sobre a câmera, vários pássaros voando pelo céu e um casal feliz passeando pelas nuvens.

Celima, neste momento trágico, lembra outras cenas da juventude do falecido, quando Alberto escapou de casa para assistir à abertura do Copacabana Palace e voltou decidido que, um dia, seria fotógrafo, como seu padrasto. Salete, ainda marcada pelo amor não correspondido, conta seu primeiro encontro com Alberto: ela sentiu 
o destino, pela primeira vez, lhe sorrir "na forma de um homem"; mas ele, vestido de pierrô, aproximou-se também de todas as outras, na "corrida dos porcos" do Bloco do eu sozinho, enquanto uma cantora cacarejava $A$ galinha carijó. Conta seu segundo encontro com o homem de sua eterna frustração, quando um zepelim cruzava o céu carioca, mas ela só olhava para o fotógrafo e não viu o acontecimento; alega, ainda zangada, que perdeu a chance de agarrar Alberto para sempre, porque interveio a Miloca.

Naquele carnaval, encontraram-se pela primeira vez Alberto e Maria Emília - Miloca - vendendo margaridas na praia "para ajudar a casa da mãe pobre", e pela qual ele acabou fazendo loucuras. O pai dela só queria um genro rico, motivo pelo qual Alberto tentou sua sorte no cassino e, apostando na roleta no número cinco vermelho, ganhou uma fortuna, mas perdeu-a toda em outra ocasião.

Um dos confidentes de Alberto sabe da existência de um álbum de fotos secretas, e a turma quer ver esta coleção delicada. Apesar da oposição de Celima, os amigos procuram-no, e, neste momento, a voz do Narrador dirige-se ao espectador:

Para vocês verem como é a vida, mal você morre e seus amigos já estão furungando estas coisas.

Todos olham, avidamente, as fotos proibidas, além das profissionais, e quando acham um retrato lindo de Miloca, Celima quer retomar aquela história de amor. A voz do Narrador, porém, impõe-se para ele contar o reencontro: nos anos setenta, ele viu, por acaso, uma senhora com seu cachorro vira-lata na praia; ficou atraído pela bizarrice daquela mulher, e quando quis tirar uma foto, reconheceu-a. Miloca fugiu, alegando que a pessoa que ele amava, não existia mais. Corte. Rogéria, ao escutar essa história de amor, contada pelo Narrador do filme, conclui que nem mesmo travesti tem tanto para contar.

De noite, quando todos no velório estão dormindo e roncando, entra Miloca. Ao inclinar-se sobre o caixão, seu rosto readquire a aparência da jovem que vendia a Alberto uma margarida. E a voz do defunto narrador comenta: 
A saudade é a sombra negra de um passado cor-de-rosa.

A narrativa fílmica traz então à memória de Miloca outro evento do passado: um elefante na praia de Copacabana. Depois, da mesma maneira como a mulher amada de Alberto apareceu, ela vai embora, deixando todos boquiabertos e - black-out.

Volta o plano geral sobre a praia, com o sublime nascer do sol, e volta, na trilha sonora, O Danúbio azul. Repete-se também o plano-seqüência para o interior do apartamento e o Narrador retoma o texto já conhecido:

É... Duas datas: a do nosso nascimento e a da nossa morte. E no meio, uma infinidade de acontecimentos: amores, dores almas que se esgarçam. E por fim ...

Esta vez, porém, não acaba a frase; a tampa não fecha. Além disso, não se trata do mesmo nascer do sol; a iluminação varia e a interpretação é, ligeiramente, diferente - tal como nos ensaios em que se repete uma cena. E morrer duas vezes num filme, acaba com qualquer ilusão de verossimilhança: a morte de Alberto torna-se um ato puramente teatral; o set cinematográfico vira palco.

A repetição tragicômica segue até o momento em que Celima enxuga a lágrima caída sobre o olho da câmera; eis aí a peripécia, anunciada pelos gritos da irmã:

\section{Ah! Ele se mexeu!}

E Alberto, segurando a estátua da Virgem de Copacabana, levanta-se do caixão, armando a maior confusão imaginável, no meio da qual Atílio entra em colapso.

Explica-se a ressurreição do "defunto" por catalepsia. Alberto retira-se e confessa a sua Santa que sabia que ela o salvaria, constatando que, exceto ele, ninguém reparou no milagre. Ao perguntar 
a sua Protetora, cuja presença é indicada pela sombra na parede do quarto, se ele morreu ou não, a Virgem pergunta pelas lembranças que lhe passavam pela cabeça no momento da pressuposta morte. Alberto começa a falar da procissão, e o espectador vê como o grupo de fiéis sai da igreja, na cidade de Copacabana, num pôr-do-sol sobre o lago Titicaca, para passar, de manhã, pela praia carioca.

Antes de ir ao hospital para visitar Atílio, surge uma discussão com respeito ao caixão: Alberto pede para que seja retirado do apartamento, mas Isaac, o amigo judeu, quer guardá-lo, se por acaso...

Ao sair do prédio, os dois empregados do condomínio reiteram suas apostas no próximo falecimento; saem juntos à rua, e um carro os atropela. A turma de Alberto, na perua que os leva ao hospital, nota que houve um acidente, sem perceber, porém, a identidade das vítimas. Surge uma conversa com máximas e colocações fúteis sobre a morte, e entre elas:

"Para morrer, basta estar vivo". É isso que dizia Machado de Assis, em Memórias póstumas de Brás Cubas...

De novo, fica a pergunta certa sobre a autenticidade da citação, formulada agora por uma protagonista:

Isso é Machado de Assis?

E acaba-se o sintagma central do texto filmico.

$* * *$

No epílogo, o protagonista está sentado num banco da avenida Atlântica, olhando para a câmera. Alberto, pela primeira vez, é filmado na posição do Narrador, dirigindo-se ao espectador, de maneira que surge a pergunta se era desde aí que o ator estava contando a vida de Alberto e, duas vezes, sua morte:

Na vida morrer não é nada. É quase como voltar para casa. Como dizia o poeta: "Dificil é a vida, e seu oficio". 
Você sabe o que realmente nos faz envelhecer? É ter nascido em 1902, 1907, 1918, 1920, 25, 30, 38, 45, 48, $50,57,63,69,70,72,79,80,89,90,95,99,2000$, 2010, 2020, 2050, 2060, dois mil e...

A voz de Caetano Veloso entoa Superbacana; a câmera como num levantar do sol - começa lentamente a subir, até que o protagonista apareça emoldurado, em plongée, pelo mosaico ondulado da calçada carioca.

$$
* * *
$$

\section{«Toda essa gente se engana...»}

Leitor estimado: você que acompanhou essa paráfrase e os respectivos excursos, em várias ocasiões, talvez tenha ficado surpreso com a minha percepção, e suponho que essa ou aquela cena evocou em você outra associação. Esta leitura é minha.

Concordo com Michael Riffaterre que, em L'illusion référentielle, ${ }^{13}$ defende a posição de que o fenômeno artístico não se deve nem à produção, nem à obra em si, senão à percepção pelo próprio consumidor:

L'approche la plus fructueuse - en fait la seule qui soit satisfaisante - consiste à prendre en compte simultanément le lecteur et le poème : celui qui interprète en même temps que ce qu'il interprète. Car ce n'est pas dans l'auteur, comme les critiques l'ont longtemps cru, ni dans le texte isolé que se trouve le lieu du phénomème littéraire, mais c'est dans une dialectique entre le texte et le lecteur.

13. In Barthes et alii, 1982: 92-93. 
U. Boccioni apóia essa teoria, dizendo que "a realidade não é o objeto, mas a transfiguração que ele sofre ao identificar-se com o sujeito". ${ }^{14}$

Embora a objetividade não exista e a recepção seja subjetiva, tentarei, com o devido cuidado, "transfigurar" meus achados no "objeto" filme em metalinguagem. Proponho-me primeiro resumir a obra, tomando em consideração os quatro itens clássicos de um resumo, que são espaço, tempo, personagens e ação; e chego à seguinte solução:

Copacabana, 2001: Alberto, um fotógrafo carioca, apresenta cenas de sua vida.

Opõe-se esse resumo sistemático, por exemplo, à sinopse, bem mais informativa e saborosa, na capa do filme em DVD:

Alberto (Marco Nanini) é um fotógrafo às vésperas de completar 90 anos. Seus amigos ruidosos e irreverentes preparam uma festa surpresa, mas Alberto parece subitamente tomado pelo passado. E é, de forma lúdica e bem-humorada, que ele volta no tempo e re-visita importantes fatos profissionais e afetivos de sua longa vida. Muitas lembranças são compartilhadas pelos amigos, como ele antigos moradores do bairro. Aos poucos, as lembranças de Alberto e a história do bairro se misturam, formando um painel da vida de Copacabana e do país desde o início do século. Ao lado de tantas lembranças dos anos dourados do bairro, que foi capital da República, contrapõe-se o cotidiano atual de Copacabana, cheia de surpresas e beleza.

A teia narrativa dificulta resumir o filme por ser organizado de tal maneira que o espectador é levado a um vai-e-vem de incongruências e oposições, entre um presente vagamente definido e os momentos do passado, a vida e a morte, a comédia e o

14. Apud Silva, 1995: 257. 
documentário, uma procissão que começa na Bolívia e que continua no Rio de Janeiro, entre um nonagenário e um jovem de vinte anos e ambos continuam sendo Marco Nanini -, entre citações falsas e verdadeiras, discretamente deslizadas nos diálogos.

Copacabana, que no desenvolvimento diegético transmite a impressão de um texto filmico marcado por incongruências, é na verdade um labirinto enigmático que estimula procurar seu centro e sua saída.

Luis Buñuel (1982: 184), numa conferência dada em 1958 sobre El cine, instrumento de poesia, na Universidade de México, define o elemento essencial de toda obra de arte pelo "mistério", lamentando-se, aliás, que este componente falte na maioria das obras cinematográficas contemporâneas:

El misterio, elemento esencial de toda obra de arte, falta, por lo general, en las peliculas. Ya tienen buen cuidado autores, directores y productores de no turbar nuestra tranquilidad abriendo la ventana maravillosa de la pantalla al mundo libertador de la poesia. Prefieren reflejar en aquélla los temas que pudieran ser continuación de nuestra vida ordinaria, repetir mil veces el mismo drama, hacernos olvidar las penosas horas del trabajo cotidiano. Y todo esto, como es natural, bien sancionado por la moral consuetudinaria, por la censura gubernamental e internacional, por la religión, presidido por el buen gusto y aderezado con humor blanco y otros prosaicos iterativos de la realidad.

Uma das características do filme é a presença de um narrador, aparentemente morto, desde o início do texto filmico, cuja situação espaço-temporal só se revela na cena final.

Esta técnica - provindo do mundo literário - lembra, entre outros, a estrutura do romance La vie devant soi (1975), do autor Romain Gary ${ }^{15}$ : Momo, um garoto abandonado pela mãe que, aparentemente, não estava em condições de criá-lo, conta sua vida a

15. O romance do autor francês de origem russa foi filmado, em 1977, por Moshé Mizrahi. 
alguém que ele chama de "vous"16. Revela-se, só no último parágrafo do texto, a situação cronotópica ${ }^{17}$ do narrador: na presença de um psicólogo, o doutor Ramon, e sua esposa Nadine, Momo conta sua vida marcada pela constante procura de alguém que o ame; o leitor, que desde a primeira página identifica-se como destinatário do relato, surpreende-se com a revelação final e precisa repensar a posição que $o$ relato the atribui.

A lista dos constituintes paralelos entre Copacabana e $\mathrm{La}$ vie devant soi engloba - além do enfoque narrativo em suspense - os motivos da criança abandonada e da mãe adotiva, proveniente de outro país, e também a temática de uma vida marcada por amor e sofrimento. $\mathrm{Na}$ obra de Gary, há um ex-vendedor ambulante de tapetes orientais, Monsieur Hamil, que ficou a vida inteira com saudade de seu primeiro amor; suas palavras exprimem sentimentos comparáveis com aqueles do velho Alberto frente a sua primeira namorada, a Miloca:

- Il y a soixante ans, quand j'étais jeune, j'ai rencontré une jeune femme qui m'a aimé et que j'ai aimée aussi. Ça a duré huit mois, après, elle a changé de maison, et je m'en souviens encore, soixante ans après. Je lui disais : je ne t'oublierai pas. Les années passaient, je ne l'oubliais pas. J'avais parfois peur car j'avais encore beaucoup de vie devant moi [...] (Gary, 1975: 11).

Ambos, Monsieur Hamil e Alberto, estão no final de uma vida cheia de "amores, dores, almas que se esgarçam"; ambos, nä juventude, tinham um grande amor inesquecível e ambos, velhinhos, preocupam-se com a iminência da morte:

Noventa anos é uma idade impossivel de se pensar num futuro alegre.

16. Tratamento que corresponde a "você", "vocês", "o senhor", "a senhora", "os senhores" ou "as senhoras".

17. Uso o termo no sentido definido por Bakhtin (1978: 237):"Nous appellerons chronotope, ce qui se traduit, littéralement par "temps-espace" : la corrélation essentielle des rapports spatio-temporels, telle qu'elle a été assimilée par la littérature." 
Falamos das incongruências chamativas do início da diegese e detivemos-nos com o desfecho surpreendente, que apresenta $o$ Narrador "ressuscitado", na Avenida Atlântica, falando com o espectador. Falta tomar em consideração a "infinidade de acontecimentos" no meio da vida do protagonista - e do filme.

Pensando bem: a maioria dos episódios apresentados informa mais bem sobre o passado histórico do bairro carioca do que sobre o personagem principal, e os trechos de documentários, às vezes, ajustam-se artificialmente a uma biografia individual. Estabelece-se, além disso, uma configuração pictórica de congruidade quando, no sintagma final, a câmera enfoca o ator em plongée, junto com a calçada, cujo desenho marcante se repete no figurino.

A união ressaltante nesse final manifestou-se já, desde o início do filme, pela projeção da sombra de Alberto sobre a calçada e reitera-se na seqüência em que aparece morto na areia. Ambas as cenas destacam-se por uma junção intrínseca entre o personagem e o solo.

O protagonista, sob a proteção de Nossa Senhora, com um passado repleto de histórias que perdeu, sim, o glamour de sua juventude, mas que não morreu e nem morrerá, pode considerar-se uma personificação metonímica do lugar.

O crítico de cinema José Geraldo Couto, num artigo intitulado Carlota Joaquina e a história no cinema, destaca a "ousadia antinaturalista", pela qual a obra "acabou por apresentar uma imagem da História viva e envolvente como poucos". ${ }^{18} \mathrm{Na}$ minha opinião, a cineasta deu sua segunda lição de História: Copacabana, além de ser outra "imagem da História viva e envolvente", cria, com

18. Cf. Couto, 1995: 112-113: “Com o astucioso artificio de apresentar a história indiretamente, imaginada por uma garotinha escocesa a partir de relato mais ou menos sensacionalista de um tio, Carla Camurati abriu caminho para que o pitoresco desse o tom de seu filme. [...]Ao contrario dos filmes históricos brasileiros feitos até agora (tanto os "oficiais" com os "criticos"), Carla Camurati voltou as costas para o naturalismo, para a mais comezinha mimese, para a busca de uma estrita verossimilhança". 
"ousadia antinaturalista”, uma figura alegórica: Alberto representa o próprio bairro.

Uma versão do sintagma final, registrada entre Cenas excluidas na cópia DVD, confirma nossa tese: o protagonista tira, frente à câmera, peruca, bigode e maquilagem; tira assim qualquer ilusão de que o filme trate de um fotógrafo chamado Alberto, para mostrar Marco Nanini, protagonista da vida cultural carioca. $\mathrm{O}$ trecho, embora esclarecedor, não aporta nada novo, já que um ator, ao interpretar o papel do mesmo personagem aos noventa e aos vinte anos de idade, força o efeito de ruptura da ilusão.

$\mathrm{O}$ uso de enfeites postiços na maquilagem do "bando dos velhos amigos" de Marco Nanini é marcante no filme inteiro, o que lhe confere uma aura teatral ou carnavalesca. Ilka Soares, que já não se está banhando nua num rio, como em Iracema (1949), fica ela mesma, ${ }^{19}$ igual aos outros "famosos", conhecidos todos como pessoas integrantes da vida cultural carioca. Nesse sentido, considero a ROGÉRIA como um(a) personagem-chave, por interpretar a si mesma; ela é "a própria" em sua vida real.

O jogo de desmascaramento do mundo da ficção teve seu auge na época barroca. Quando Sganarelle, na última cena de Dom Juan de Molière, gritava, em 1665, "Mes gages! mes gages, mes gages!", não era só o servidor mal pago do grande libertino que pedia seu salário; interpretado pelo próprio autor, virou um alerta do diretor do elenco lançado ao público para que a apresentação fosse, devidamente, remunerada.

A primazia da estrela sobre seu papel reaparece, last but not least, na comédia musical homônima de 1947: Carmen Miranda interpreta uma Carmen Navarro, cantora brasileira com ambições de encaixar-se no mundo do show business americano, e o consegue.

19. Cf. Renato Luiz Pucci Jr., num artigo intitulado Copacabana mon amour (não publicado): "Olho para a ficha técnica de Copacabanae vejo ali o nome de Ilka Soares. [...] vi-a em filmes dos anos cinqüenta, como Modelo 19, Esquina da llusão e Floradas na Serra. Vou até meus livros e encontro duas fotos de llka: mocinha, banhando se nua num rio, em Iracema (1949), e mais madura, na capa do dicionário de Astros e Estrelas do Cinema Brasileiro." 
Nesse sentido, os dois longas-metragens têm algo em comum: representar a si mesmo.

Copacabana, ao meu ver, norteia-se também pela comédia almodovariana, que trabalha em primeiro lugar com elementos de ficção visível: "Teatro, puro teatro" canta La Lupe no final de Mujeres al borde de un ataque de nervioss, que originalmente era um projeto de adaptação da peça La voix humaine (1930), de Jean Cocteau. O cineasta da terra de D. Quixote, para quem a comédia é "el más artificial de los géneros" (Almodóvar, 1995: 94) declarou com respeito a isso:

La comedia es un género grande profundo, porque es el único que no cuenta lo que se ve en la pantalla, sino otra cosa. Y tampoco es un género ambiguo. Yo diría que no lo es en absoluto. He querido hacer deliberadamente una comedia, y ya es hora de que se enteren de que la comedia es lo más dificil de hacer en cine, porque exige una precisión absoluta; cualquier titubeo en el tiempo es mortal (García De León \& Maldonado, 1989: 167).

Impõe-se a pergunta: o que conta então Copacabana se não é o que se vê na tela? Tentemos reformular nosso resumo:

Copacabana, 2000/2001: Marco Nanini, fazendo o papel de um fotógrafo carioca, apresenta várias cenas de Copacabana.

Fica, no entanto, a dúvida se as indicações cronotópicas são corretas: embora apareça na tela o bairro carioca, é possível que, por exemplo, o banquinho na calçada, na última cena, seja um set cinematográfico. Defino 2000 pelo ano de produção e 2001 pelo lançamento do filme, do rap de Bia Pontes e pela alusão ao filme 2001: a Space Odyssey; no entanto, a datação fica incerta.

Um filme que se preocupa em não manter a ilusão cinematográfica, rompendo-a, propositalmente, e que também não é 
um documentário, dificulta bastante sua definição espaço-temporal. O que parece, não precisa ser. De certa maneira, o filme nega sua fixação num contexto geográfico-histórico; em vez de definir seu hic et nunc, trama uma teia para escapar a uma definição inequívoca.

Para chegar a uma conclusão mais sólida, valho-me de um esquema que Rosalind E. Krauss descreve e aplica, nas análises de percepções visuais, em sua obra The Optical Unconscious, ${ }^{20}$ para detectar "o inconsciente ótico" de nosso filme.

Um evento histórico fica definido pelos itens Tempo (quando?) e Espaço (onde?), enquanto um sonho, uma utopia ou uma ficção pode escapar a uma definição cronotópica.

Ao adaptar o gráfico da historiadora de arte norte-americana, marcamos, no eixo superior do quadro, os itens que definem a cronotopia e, no eixo inferior, a negativa dos conceitos definidores, chamando-os de Não-Tempo e Não-Espaço:

TEMPO

EsPaço

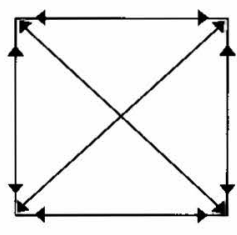

NÃO-TEMPO

NÃo-EsPaÇO

Os trechos de documentários intercalados em Copacabana - a passagem do zepelim, por exemplo - são definíveis pelo eixo superior $(\mathrm{T}+\mathrm{E})$; uma foto ou uma contribuição para o noticiário foi feita em

20. A autora usa o esquema estruturalista, para discutir a distinção entre Figura e Fundo / Não-Figura e Não-Fundo, por exemplo, na análise dos quadros de Frank Stella e Piet Mondrian: "I start with a square. In its upper right corner I write figure and in its upper left I write ground. I want this square to represent a universe, a system of thinking in its entirety, a system that will be both bracketed by and generated from a fundamental pair of oppositions" (Krauss, 1998: 13). 
tal lugar e em tal momento, ficando assim inscrita na historicidade, e nem é preciso se lembrar onde e quando o documento foi feito: a definição cronotópica existe. Do mesmo modo, definimos as cenas de ficção histórica, como a Revolta do Forte (1922) ou a abertura do hotel Palace (1923): ambos acontecimentos "tiveram lugar" e levam data.

De fato, o filme mostra uma série de acontecimentos da história local; Carla Camurati, pesquisando nos arquivos, reuniu um magnífico material pouco conhecido para compor a fita. E é certo: um evento histórico enfatiza a importância do lugar, porém só se for lembrado. ${ }^{21}$

Além dessas cenas históricas - descritiveis pelo eixo superior do esquema - apresenta o filme uma série de sintagmas que escapam a uma definição cronotópica.

Seria uma tarefa dificílima estabelecer uma ordem cronológica de cada seqüência da fita. Supondo que o "grau zero"22

21. Bakhtin, ao descrever, em Estética da criação verbal (2000: 262), a função de eventos históricos numa obra literária - particularmente nos textos de Johann Wolfgang von Goethe que ancoram em fatos históricos e geográficos -, registra os seguintes impactos sobre a obra de fiç̧ão:

- a fusão do tempo (entre o passado e o presente),

- a marca nitidamente visivel do tempo inscrita no espaço,

- a união indissolúvel do tempo do acontecimento ao lugar concreto de sua realização (Lokalität und Geschichte),

- o vinculo substancial e visivel que liga os tempos (o presente ao passado),

- a atividade criadora do tempo (do passado no presente e do próprio presente),

- a necessidade que penetra o tempo, que liga o tempo ao espaço o os tempos entre si,

- e, finalmente, com base na necessidade que impregna o tempo espacializado, a inserção do futuro que assegura a plenitude ao tempo tal como ele aparece nas imagens de Goethe.

O que vale nos textos de Goethe também tem valor num filme que trabalha com material histórico. E concluimos, junto com Bakhtin (2000: 245), que o visivel representa, para ambos, "não só a primeira, mas também a última instância, aquela em que o visivel já está enriquecido e imbuido de toda a complexidade do sentido e do conhecimento".

22. Uso o termo no sentido de Roland Barthes - Le degré zéro de l'écriture (1972) ["O Grau Zero da Escrita (2000)"], para designar o hic et nunc da narração, e não como "grau zero de estilo cinematográfico", definido por Noel Burch (1992: 31 ), pois o olhar do protagonista, ao dirigir-se ao espectador, seria considerado uma ruptura da expressão "realista". 
da narração fílmica seja o final, a obra inteira torna-se uma mistura de lembranças e recordações individuais - correspondendo à vida privada de Alberto -, ou coletivas - que mostram momentos da história do bairro carioca. Ao longo do filme, sobrepõem-se presente e passado de tal maneira que o espectador já não consegue distinguir entre diegese e flash-back, e a última frase do protagonista dispensa, inclusive, o futuro de sua temporalidade, ao dizer que envelhecer é o fato de "ter nascido em [...] 2010, 2020, 2050, 2060, 20...".

A teia do filme foge ao eixo superior do quadro, para basearse, poeticamente, na sua diagonal entre as pontas Espaço e NãoTempo, o que dispensa o lugar de sua efemeridade: o planet Copacabana - igual a Alberto - não morre.

Além de atribuir ao lugar - o verdadeiro protagonista da obra - uma auréola de fama eterna, as urdiduras da composição conferem-lhe também o atributo de internacionalidade, ao sobrepor espaços diferentes. Lembremo-nos da procissão da Virgem, que sai de seu santuário à beira do lago Titicaca e chega - enquanto a câmera enfoca a estátua com o céu - à praia carioca. ${ }^{23}$ Os espaços reais da filmagem, depois de juntá-los no estúdio, formam um amálgama episódico sem vínculo geográfico realista. A junção de um ato inscrito no tempo - a procissão - e de dois espaços distantes dispensa a cena de ser percebida como um evento real. A procissão, ao definila pelos conceitos em diagonal Tempo e Não-Espaço, vira um acontecimento sonhado: Copacabana como lugar "u-tópico", no próprio sentido da palavra.

O fazer artístico, ao integrar os itens Não-Tempo e NãoEspaço na trama do filme, confere-lhe uma dimensão além da realidade onírica ou poética, o que Buñuel já definiu como elemento essencial da sétima arte.

23. A filmagem em contre-plongéeda estátua de Nossa Senhora de Copacabana no andor, com o céu no fundo - sendo ela o objeto que une os tempos e espaços diferentes - lembra o maior cut da história de cinema, que junta um lapso de tempo de quatro milhões de anos: em 2001: a Space Odyssey, um macaco joga um osso no ar, e sua arma se converte em uma nave espacial, seguindo rumo à Lua. Os dois objetos - o osso e a nave - assemelham-se pela forma exterior, e ambos servem de armas. 


\section{"E no meio, uma infinidade de acontecimentos..."}

Concluamos nossa odisséia por Copacabana, detendo-nos ainda um pouco nos meandros narrativos da parte central, com sua "infinidade de acontecimentos", entre os quais atribuímos uma posição de destaque ao sintagma do carnaval na praia. No velório, os amigos do defunto lembram a corrida dos porcos, os primeiros amores e a fantasia de Alberto: vestido de Pierrot, o que estabelece um "vínculo substancial e visivel que liga os tempos" (Bakhtin, 2000: 262). O fato de baralhar uma cena carnavalesca e uma cena fúnebre dispensa o luto indicado. Esses "diálogos no limiar"24, à beira do caixão aberto, que juntam os momentos extremos da existência humana, em sua seiva e na agonia, podem considerar-se uma forma de riso ritual, ou riso fúnebre, que Bakhtin (1997: 126-127) atribui à tradição de uma vida carnavalesca:

O próprio riso carnavalesco é profundamente ambivalente. Em termos genéticos, ele está relacionado às formas mais antigas do riso ritual. Este estava voltado para o supremo: achincalhava-se, ridicularizava-se o sol (deus supremo), outro deuses, o poder supremo da terra para forçá-los a renovar-se. Todas as formas do riso

24. "Em Platão, na Apologia, a situação do julgamento e da sentença de morte esperada determina o caráter especial do discurso de Sócrates como confissão-prestação de contas de um homem que se encontra no limiar. [...] Contudo, já podemos falar do surgimento de um tipo especial de "diálogo no limiar" (Schwellendialog) em base dialógica socrática, e esse tipo especial é amplamente difundido na literatura dos periodos helênico e romano, posteriormente na ldade Média e, por último, na literatura do Renascimento e do periodo da Reforma" (Bakhtin, 1997: 111). "O gênero do 'diálogo no limiar' também foi amplamente difundido na ldade Média, tanto nos gêneros sérios quanto nos cômicos (por exemplo, a famosa trova do camponêsque discute às portas do paraiso), e representado com amplitude especial na literatura do periodo da Reforma, a chamada 'literatura das portas do céu' ('Himmelspforten-Literatur')" (ibidem: 116). 
ritual estavam relacionadas com a morte e o renascimento, com o ato de produzir, com os simbolos da força produtiva. O riso ritual reagia às crises na vida do sol (solstício), às crises na vida da divindade, na vida do universo e do homem (riso fúnebre). Nele se fundiam a ridicularização e o júbilo.

[...] O riso abrange os dois pólos da mudança, pertence ao processo propriamente dito de mudança, à própria crise. No ato do riso carnavalesco combinam-se a morte e o renascimento, a negação (a ridicularização) e a afirmação (o riso de júbilo). É um riso profundamente universal e assentado numa concepção do mundo. É essa a especificidade do riso carnavalesco ambivalente.

A cena do festejo popular metonimicamente evocada adquire uma significação metafórica que carnavaliza a contextura filmica: a obra, além de apresentar "le monde à l'envers", ancora, semanticamente, na essência do Carnaval e acaba sendo compreendido como sua própria expressão: Copacabana é um carnaval cinematográfico.

Bakhtin distingue quatro categorias determinantes do espetáculo carnavalesco: a familiarização, a excentricidade, as mésalliances e a profanação. $\mathrm{Na}$ teia do texto fílmico, há-as todas entretecidas:

1. O livre contato familiar ${ }^{25}$ entre diferentes grupos sociais é lindamente encenado, na festa de aniversário de Alberto, em que participam, além dos amigos íntimos, o menino engraxate da rua, duas prostitutas cheirando cocaína no banheiro, um padre em

25. "No carnaval forja-se, em forma concreto-sensorial semi-real, semi-representada e vivenciável, um novo modus de relações mútuas do homem com o homem, capaz de opor-se às onipotentes relações hierárquico-sociais da vida extra carnavalesca. O comportamento, o gesto e a palavra do homem libertam-se do poder de qualquer posição hierárquica (de classe, título, idade, fortuna) que os determinava totalmente na vida extracarnavalesca, razão pela qual se tornam excêntricos e inoportunos do ponto de vista da lógica do cotidiano não-carnavalesco" (Bakhtin, 1997: 123). 
discussão com o doceiro judeu, o travesti Rogéria e um rebuliço de pessoas sem identificação.

2. A excentricidade, definida como "uma categoria especifica da cosmovisão carnavalesca", que "permite que se revelem e se expressem - em forma concreto-sensorial - os aspectos ocultos da natureza humana" (Bakhtin, 1997: 123) encarnam os travestis dos enquadramentos documentários e Rogéria, queixando-se de que a juventude de hoje não tem o devido respeito aos cabelos tingidos. Sua mise en scène na festa surpreende com um novo chapéu, modelo "bolo de aniversário", com as indispensáveis velas. "O emprego de objetos ao contrário: roupas pelo avesso, calças na cabeça, vasilhas em vez de adornos de cabeças, utensílios domésticos como armas, etc.", é, na definição de Bakhtin, (ibidem), também, "uma manifestação especifica da categoria de excentricidade, da violação do que é comum e geralmente aceito".

3. As "mésalliances" carnavalescas, definidas pela combinação do sagrado com o profano, o elevado com o baixo, o grande com o insignificante, o sábio com o tolo, têm sua expressão, por exemplo, no ato de olhar o álbum de fotografias pornográficas durante o velório, na presença da boneca inflável ao lado do féretro, na valsa vienense que acompanha a panorâmica sobre Rio de Janeiro.

4. A escada que leva ao bordel de Madame Cosette está enfeitada com uma estátua de Nossa Senhora de Copacabana. A justaposição da santa e da prostituta - os dois pólos que norteiam a vida do protagonista -, sirva de exemplo para a profanação.

A ação carnavalesca principal, segundo Bakhtin, é a coroação bufa e o posterior destronamento de rei do carnaval. ${ }^{26}$

26. "Na base da ação ritual de coroação o destronamento do rei reside o próprio núcleo da cosmovisão carnavalesca: a ênfase das mudanças e transformações, da morte e da renovação. O carnaval é a festa do tempo que tudo destrói e tudo renova. Assim se pode expressar a idéia fundamental do carnaval“ (Bakhtin, 1997: 124). 
A trilha sonora Planet Copacabana coroa "a princesinha do mar [...] bem junto ao céu", e a destrona do caminho porque já "tem em cada esquina / Uma garota de quatorze que é a nova princesinha".

Os exemplos não faltam; as metáforas de carnavalização vestem cada tessitura do filme com a devida fantasmagoria. Copacabana, além de ser o topônimo da glamourosa praia carioca, torna-se, ao nível da ficção, no Não-Espaco onde a cena da morte é repetível e onde acontece - acronicamente - o que foi e o que "não teve lugar": Copacabana, o espaço filmico, torna-se uma praça utópica do Grande Carnaval, onde se misturam épocas e lugares diferentes, se juntam velhice e juventude, se amalgamam enunciado e enunciação. Os colegas de Alberto, todos visivelmente fantasiados, são, ao mesmo tempo, "o bando de velhos amigos" atores de Marco Nanini disfarçados em personagens. Os "diálogos no limiar" dãose à beira de um caixão aberto, onde está colocada a câmera que visualiza o olhar do protagonista defunto e, ao mesmo tempo, do espectador vivo, metonimicamente deitado no meio da cena.

Cabe lembrar que Bakhtin define o carnaval como "um espetáculo sem ribalta $e$ sem divisão entre atores $e$ espectadores". 27

A câmera subjetiva, ao subir a escada, na cena da visita da casa da Mère Louise, por exemplo, faz descer o espectador no submundo do fútil prazer, deixando-o exposto às olhadas provocantes das falsas francesas.

Quem observa Les demoiselles d'Avignon (1907), de Pablo PICASSO, fica na mesma confrontação: as cinco "personagens femininas assumem uma disposição que cria no espectador da tela a ilusão de se sentir parte do espetáculo representado, pois, segundo o crítico [Leo Steinberg], as mulheres não mantêm, no espaço do quadro, uma relação comunicativa entre si: elas

27. "No camaval todos sāo participantes ativos, todos participam da ação carnavalesca. Não se contempla e, em termos rigorosos, nem se representa o carnaval, mas vive-se nele, e vive-se conforme as suas leis enquanto estas vigoram, ou seja, vive-se uma vida carnavalesca. Esta é uma vida desviada da sua ordem habitual, em certo sentido, uma 'vida às avessas', um 'mundo invertido' ('monde à l'envers')" (ibidem: 122-123). 
apenas se relacionam para implicar o observador" comenta Eduardo Peñuela Cañizal (1996: 13-14). E sabemos que "esta cena, que por si mesma diz muito, representa segundo o próprio dizer de Picasso o interior de uma casa de prostituição da Carrer d'Avinyó [Rua de Avinhão] em Barcelona, e não tem, pois, qualquer relação direta com a cidade francesa do mesmo nome" (Warncke, 1999:160).

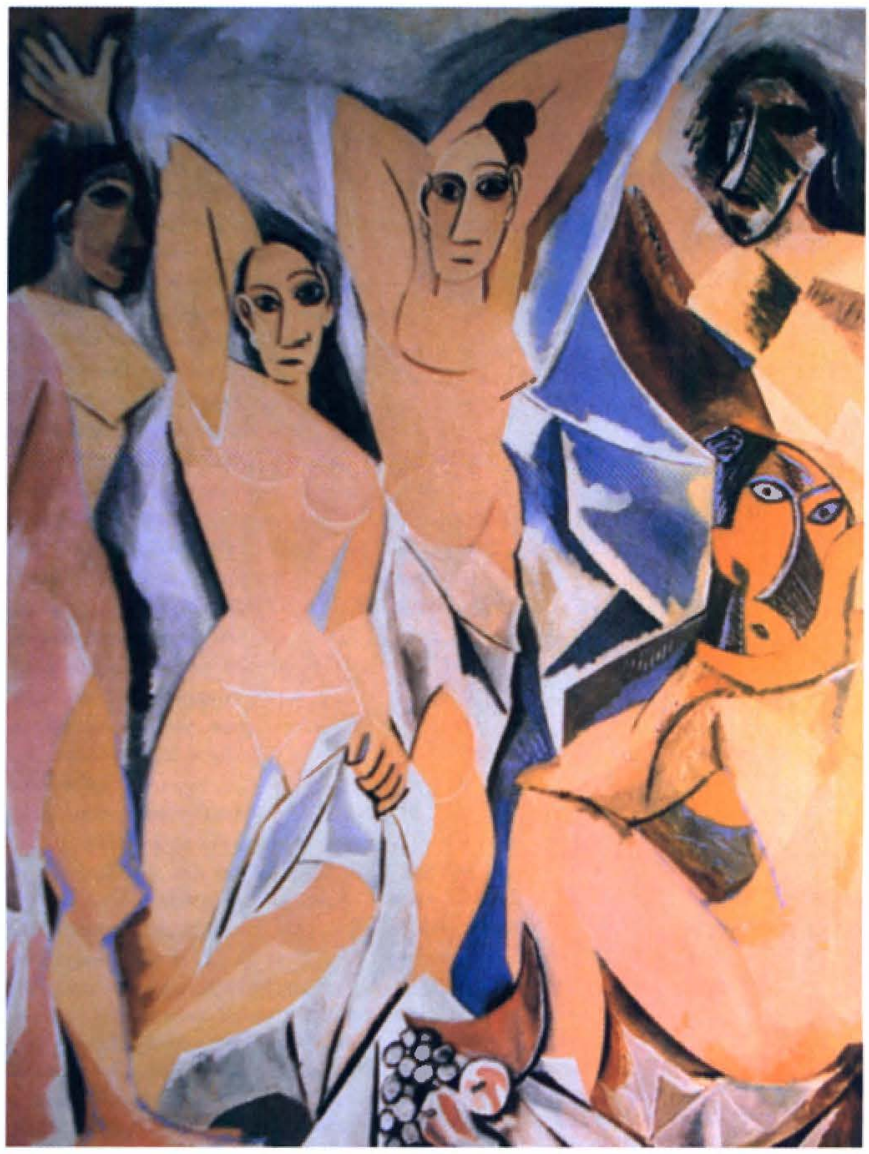

Um dos sintagmas do prostíbulo, filmado com a câmera na mão, confronta o espectador às olhadas de cinco Graças profissionais, obsequiando-o com todos seus méritos expostos. 
Conforme o arranjo do óleo de Picasso, há uma deusa de amor, sentada, à direita, numa posição vistosa, sobre uma cadeira, e outra, à esquerda, apoiada na parede, mostrando o volume de seus encantos.

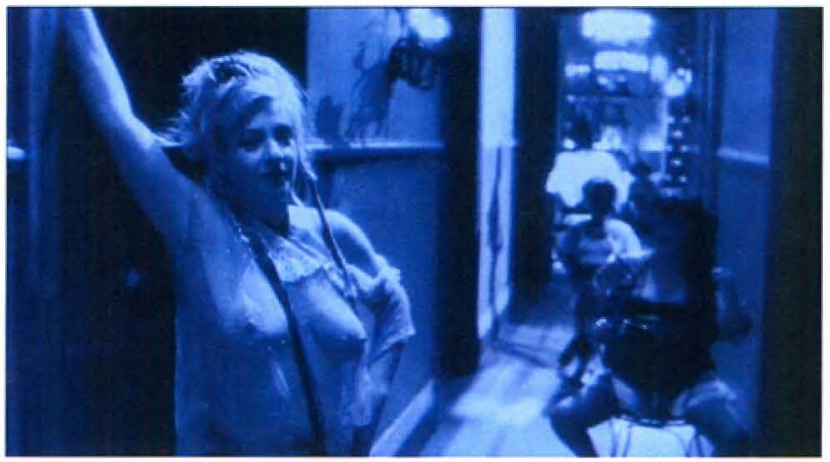

Entra na cena e, logo a seguir, sai do enquadramento um jovem sem camisa: há, nos esboços para As meninas de Avinhão, um desenho de um marinheiro que, na versão final, foi excluído.

A breve seqüência na casa das "francesas de araque" apresenta-se como uma encenação carnavalesca do quadro reputado: ambas cenas envolvem o espectador, adentrando-o num ambiente de falsas aparências, expondo-o a um jogo de olhares sedutores e deslocando-o num "demi-monde" regido pelo desejo e pelo gozo.

Eduardo Peñuela Cañizal (1996: 19-21), numa visão de conjunto da produção cinematográfica espanhola, faz o balanço de que o denominador comum dos principais cineastas espanhóis é a poética da família:

O tema da família assume formas muito diversas, mas, no caso do cinema espanhol, ele percorre veredas que passam pelas circunstâncias do social e se adentram nos porões do inconsciente. Nesse percurso, os desastres da guerra civil não só deixaram sinais da tremenda hecatombe, mas trouxeram à tona nódoas primordiais, já que, 
ao se deteriorar as relaçôes sociais e os espaços da convivencia coletiva terem ficado, por assim dizer, mais reduzidos, a familia teve de enfrentar seus fantasmas mais intimos, vendo-se obrigada a desvelar segredos e a dessoterrar velhos fantasmas. [...] Pode-se dizer, por conseguinte, que a deterioração das relações sociais e os ditames da censura foram, embora possa parecer paradoxal, os motivos que levaram os principais cineastas espanhóis à construção de uma poética da familia.

Copacabana de Carla Camurati - concluo - é um microcosmo semântico com todos seus requintes que baliza uma poética do carnaval.

$$
* * * * *
$$

\section{Bibliografia}

ALMODÓVAR, Pedro.Un cine visceral: conversaciones con Frédéric Strauss. Madrid: El País, 1995.

ARASSE, Daniel Le détail. Paris: Flamarion, 1992.

ASSIS, Joaquim Maria Machado de Memórias póstumas de Brás Cubas. Rio de Janeiro, Garnier, 1988.

BARTHES, Roland.Le degré zero de l'écriture. Paris: Seuil, 1972. et alii. Littérature et réalité. Paris: Seuil, 1982.

BÄTZNER, Nike.Mantegna. Köln: Könemann, 1998.

BAKHTIN(E), Mikhail.Estétique et théorie du roman. Paris: Gallimard, 1978.

Problemas da poética de Dostoiévski. Rio de Janeiro: Forense Universitária, 1997.

A cultura popular na Idade Média e no Renascimento:

o contexto de François Rabelais. São Paulo: Hucitec, 1999.

BAKHTIN(E). Estética da criação verbal. São Paulo: Martins Fontes, 2000. 
BANDEIRA, Manuel. Poesia completa e prosa. Rio de Janeiro: Nova Aguilar, 1990.

BORGES, Jorge Luis. Obras completas. 4 tomos. Barcelona: Emecé, 1989.

BUÑUEL, Luis. Obra literaria. Zaragoza: Heraldo de Aragón, 1982.

BURCH, Noel. Práxis do cinema. São Paulo: Perspectiva, 1992.

BUTCHER, Pedro. Abril despedaçado : história de um filme. São Paulo, Schwarcz, 2002.

COUTO, José Geraldo. "Carlota Joaquina e a História no cinema". In: Imagens, 04. São Paulo: UNICAMP, 1995.

FREUD, Sigmund. Freud-Studienausgabe. 11 Bände. Frankfurt am Main: Fischer, 1989.

GARCÍA DE LEÓN, Maria \& Maldonado, Teresa. Pedro Almodóvar, la otra España cañi (sociología y crítica cinematográficas). Ciudad Real: BAM, 1989.

GÓMEZ DE LA SERNA, Ramón. Total de greguerías. Madrid: Aguilar, 1955.

KRAUSS, Rosalind E.The optical unconscious. Cambridge, Massachusetts, London: MIT Press, 1998.

MACHADO, José Pedro. Dicionário onomástico etimológico da língua portuguesa. 3 tomos. Lisboa: Confluência, s.d.

MANRIQUE, Jorge. Obra completa. Barcelona: Ediciones 29, 1978.

NASCIMENTO, Geraldo Carlos do. "O tempo mnésico da enunciação e o tempo crônico do enunciado em Carlota Joaquina". In: Significação 16, São Paulo: Annablume, 2001.

PEÑUELA CAÑIZAL, Eduardo (org.) Um jato na contramão: Buñuel no México. São Paulo: COM-ARTE-ECA, Perspectiva, 1993.

. Urdidura de sigilos: ensaio sobre o cinema de Almodóvar. São Paulo: Annablume / ECA-USP, 1996.

REZENDE, Antonio Paulo.Uma trama revolucionária? Do Tenentismo à Revolução de 30. São Paulo, Atual, 1991.

SILVA, Ignacio Assis. Figurativização e metamorfose: o mito de Narciso. São Paulo: UNESP, 1995.

TESSON, Charles. Luis Buñuel. Paris: Cahiers du cinéma, 1995.

WARNCKE, Carsten-Peter. Picasso. Köln: Benedikt Taschen, 1999. 